OPEN ACCESS

Edited by:

Bálint Balázs,

Environmental Social Sciences

Research Group, Hungary

Reviewed by:

Daniel Keech,

University of Gloucestershire,

United Kingdom

Christina McGee Schiavoni,

Independent Researcher, Bangkok,

Thailand

*Correspondence:

Galina Kallio

galina.kallio@helsinki.fi

Specialty section:

This article was submitted to

Social Movements, Institutions and

Governance,

a section of the journal

Frontiers in Sustainable Food Systems

Received: 29 June 2020

Accepted: 15 October 2020 Published: 25 November 2020

Citation: Kallio G and Houtbeckers E (2020) Academic Knowledge Production: Framework of Practical Activity in the

Context of Transformative Food

Studies.

Front. Sustain. Food Syst. 4:577351

doi: 10.3389/fsufs.2020.577351

\section{Academic Knowledge Production: Framework of Practical Activity in the Context of Transformative Food Studies}

\author{
Galina Kallio ${ }^{1 *}$ and Eeva Houtbeckers ${ }^{2}$ \\ ${ }^{1}$ Faculty of Agriculture and Forestry, Ruralia Institute, University of Helsinki, Helsinki, Finland, ${ }^{2}$ Department of Design, School \\ of Arts and Design, Aalto University, Helsinki, Finland
}

We have seen an emergence of transformative food studies as part of sustainability transitions. While some scholars have successfully opened up their experiences of pursuing transformation through scholar-activism, assumptions underlying researchers' choices and how scholars orient to and go about their work often remain implicit. In this article, we bring forth a practice theoretical understanding of knowledge production and advocate that researchers turn to examining their own research practice. We ask how to make our own academic knowledge production/research practice more explicit, and why it is important to do so in the context of transformative food studies. To help scholars to reflect on their own research practice, we mobilize the framework of practical activity (FPA). We draw on our own experiences in academia and use our ethnographic studies on self-reliant food production and procurement to illustrate academic knowledge production. Thus, this article provides conceptual and methodological tools for reflection on academic research practice and knowledge production. We argue that it is important for researchers to turn to and improve their own academic practice because it advances academic knowledge production in the domain of transformative food studies and beyond. While we position ourselves within the qualitative research tradition, we believe that the insights of this article can be applied more broadly in different research fields and across various methodological approaches.

Keywords: knowledge production, academic practice, research methods, reflection, practice epistemology, practice theory, transformative food studies, food economy

\section{INTRODUCTION}

Increased concerns over the adaptability of food systems to ongoing changes in local climates, and awareness of the possibility to mitigate ecosystem collapses, have raised the need for academic knowledge to contribute to building resilient, ecologically stable, and socially and economically just food systems (Allen, 2010; Foley et al., 2011; OECD, 2020). But while knowledge production is central to science (Kuhn, 1970), reflecting on the means and processes of knowledge production has not always been central to scientific work (Callon, 1984; Barad, 2003; Harding, 2008). This has distanced not only natural sciences, but also and equally social sciences, from the practices they tend to study, creating a false dichotomy between "theory" and "practice" (Eikeland and Nicolini, 2011; Sandberg and Tsoukas, 2011). 
Our aim is to help researchers reflect on their own research practice and thereby invoke discussion about the different ways in which people orient toward academic practice. Despite the several "turns to practice" within the social sciences (Ortner, 1984; Reckwitz, 2002; Miettinen et al., 2009), it is not common for academics to turn to one's own research practice to reflect on how knowledge is produced, why scholars perform research in particular ways, and what they pursue in doing so (Eikeland and Nicolini, 2011, p. 166, Stengers, 2017, but see also Räsänen, 2012, 2014; Parker, 2018). In this sense, we are not advocating for scholars to bridge the gap between "theory" and "practice" (see e.g., Sandberg and Tsoukas, 2011; Derickson and Routledge, 2015; Routledge and Derickson, 2015); rather, we seek to bring forth an understanding of academic research as a particular practice (Bourdieu, 1990; Räsänen, 2009) that is characterized by knowledge production (Kuhn, 1970; Stengers, 2017). Understanding and being capable of reflecting on one's own research practice is important not only because this enables academic scholars to (1) be more conscious about their research designs and theory development, and (2) improve processes of knowledge production (Nicolini, 2009), but also because (3) academic practice may be part of the problem when researchers reproduce the underlying paradigms that have led to the ongoing ecological, economical and societal crises in the first place (Stengers, 2017).

In this article we seek to raise awareness of knowledge production in the context of academia and transformative food studies in particular. We use the concept of transformative food studies to bring together research that addresses food as a nexus to achieve more sustainable, ecological, fair, diverse and locally distinctive societies (see e.g., Figueroa, 2015). Such research includes discussions that take place under food sovereignty, food citizenship and alternative food networks-to name but a few. While these studies capture a wide spectrum of scholarly activism, several underlying assumptions about researchers' choices and their underlying orientation remain implicit. Moreover, while many refer to the difficulties of working as an activist-scholar (Croog et al., 2018; Reynolds et al., 2018), the broader trends in academia, including the rise of the knowledge economy (Stengers, 2017), new public management (Räsänen, 2008), and neoliberal values and academic capitalism (Parker, 2018), and their influence on the everyday lives of scholars and their research practice more broadly, may go unmentioned.

Thus, we set out to ask: how do we make our own academic knowledge production/research practice more explicit and why is it important to do this in the context of transformative food studies? Although we are driven by the need to reflect on the academic practice of knowledge production by drawing on the context of transformative food studies, this article stems from our own experiences of participating in academic practices in the global North that may not be relevant to all transformative food scholars. However, we believe that making the local struggles of scholars visible also reveals how what appears possible and impossible has been translocally institutionalized into academic practices of knowledge production (Räsänen, 2009; Stengers, 2017).
In this paper, we explore the questions using two moves. First, we introduce a practice theoretical approach to knowledge production, after which we present the framework of practical activity (FPA), developed by a group of scholars close to us. We suggest that the concept of practice and the framework of practical activity are particularly helpful in conceptualizing academic knowledge production in transformative food studies. Second, we reflect on our own experiences in academia when doing research in the context of self-reliant food production and procurement practices in Finland. One of the authors has studied food collectives and smallholdings in the field of regenerative agriculture (Kallio, 2018, 2020, for a definition of regenerative agriculture, see e.g., Rodale Institute 2020), while the other has focused on households striving for selfsufficiency (Houtbeckers, 2018). Our ethnographic journeys have included various struggles and decisions, some of which we have articulated in this paper. By conceptualizing our own research practice with practice theories and the FPA elaborated later in this paper, we argue that turning researchers toward their own practice advances academic knowledge production in the domain of transformative food studies and beyond, and enables scholars to reflect on and improve academic research practice.

In what follows, we first map the domain of transformative food studies. Second, we introduce the practice theoretical approach and elaborate on how knowledge production is understood from this perspective. As an example of one practice theoretical approach, we take the framework of practical activity (FPA) and discuss how it enables reflection in practice. We then introduce our empirical studies in two separate sections: first by describing our path in academia, the context of self-reliant food production and procurement and the methods used in our ethnographies, and second by providing vignettes on our own research practice in order to make our production of academic knowledge more transparent. Finally, we discuss how researchers can make their own production of academic knowledge explicit by mobilizing the FPA in the context of transformative food studies. We end with conclusions and provide answers to why it is important to make our own academic knowledge production explicit.

\section{TRANSFORMATIVE FOOD STUDIES}

By transformative food studies, we refer to the call for food system transformations and the need for transformative food politics that would address "the root causes of current challenges within the industrial food system, rather than just the symptoms" (Levkoe, 2011, p. 688). Ongoing discussions that take place about, e.g., food sovereignty, food citizenship, and alternative food networks connect food with achieving more sustainable, ecological, fair, diverse and locally distinctive societies. As a domain, transformative food studies attracts scholars from various disciplines, including critical geography, sociology, anthropology, and more recently organization and management studies. Our own background is in organization studies, in which the focal journals of the field, e.g., Organization Studies, Organization and Human Relations, have hosted discussions in 
the intersection of organizing and food transformations (see, e.g., special issues Briner and Sturdy, 2008; Croidieu et al., 2017; Böhm et al., 2020). Although there were other concepts that we could have used in order to engage in academic discussions related to the phenomena we have studied, we consciously chose to use transformative food studies, which, to our knowledge, has little previous application. With this choice we create an overarching domain that can be used to capture the great diversity of food studies, which includes discussions on local/alternative food movements, networks, and economies.

Since conceptual choices always carry meanings that emerge from particular research traditions (MacIntyre, 1985), they end up defining and describing the phenomenon under study by infusing the knowledge that may arise from very distinct research designs and purposes. In the domain of (transformative) food studies, for instance, local food initiatives can be framed as social movements that are positioned against globalized food markets (Weber et al., 2008; Starr, 2010; DeLind, 2011), after which, e.g., framing theories drive research toward emphasizing discourses and media analysis instead of analyzing the actual activities. These analyses often undermine diverse and potentially conflicting pursuits within food movements that may extend beyond resistance, or globalized politics (Delind, 2006). Similarly, while alternative food networks (AFN) is an established concept (Goodman et al., 2011), this conceptualization implicitly suggests that alternatives are more desirable, but still marginal, compared to the dominant modes of organizing. Moreover, the underlying assumptions about sustainability in these networks are rarely problematized (Forssell and Lankoski, 2015), nor is it common to question the tendency to designate local food initiatives/economies as alternative and thereby define them as resistance to dominant practices-hence marginalizing various self-reliant pursuits.

Moreover, concepts give scholars power (Croog et al., 2018; Levkoe et al., 2019) that in turn allows them to undermine dimensions that may be central to knowledge production. For instance, despite its emancipatory objectives, citizen science can contribute to separating "science professionals" from "practitioners" and "amateurs" (see e.g., Conde, 2014) and end up granting more value to scientific measurement than to embodied and non-articulable ways of knowing (see e.g., Barad, 2003; de la Bellacasa, 2016). By putting more weight on "expert knowledge," scholars may fail to understand that "amateur-practitioners" can also be "experts" of their own practice (Gherardi, 2012; Räsänen, 2015). Consequently, there is a danger that research produces food studies based on Western knowledge (Jehlička et al., 2020), and thus reproduces neoliberal agency and individualistic understandings of human behavior (Alkon and Mares, 2012), among other things.

In contrast, some of the research that we call transformative food studies seems to include reflection on knowledge production that characterizes academic research practice. In opposing the colonial concept of food security, food sovereignty provides one successful example of scholarship from which knowledge production often arises in collaboration with the grassroots actors (Patel, 2009), and many food sovereignty scholars seek to acknowledge the unequal power relationships between the researchers and the researched. In this domain,
Figueroa (2015), for instance, proposes a people-centered approach accounting for the everyday life experiences of the studied people. They make visible how conceptualizations start to carry cultural meanings and political interests-often Western, neoliberal and racialized-that are infused into the phenomenon under study. The concept of food deserts is one such example. By opening up their own research processes and experiences, (Levkoe et al., 2019) suggest three pillars that enable researchers to account for the perspectives, needs and vocabulary of those who are researched. The suggested pillars of people (humanizing research relationships), power (equalizing power relations) and change (pursuing transformative orientations) support academic praxis, a concept that the authors use to refer to transformative knowledge production.

Along these lines, Croog et al. (2018) bring forth a critical perspective on academic knowledge production and argue that " $[r]$ esearch' in any shape or form necessarily acts within and upon the sociopolitical context in which it occurs" (Croog et al., 2018, p. 1025). The authors raise several concerns about academic practice not being supportive of politically engaged and meaningful research across different scientific disciplines. They plead for bringing those values into the center of an academic practice that embraces co-production of knowledge, transformation centered research and the emergence of the scholar-activist paradigm.

While scholar-activism and critical reflection on knowledge production characterize transformative food studies (Wakefield, 2007; Levkoe, 2011; Derickson and Routledge, 2015; Routledge and Derickson, 2015; Reynolds et al., 2018), many underlying pursuits and assumptions of scholars remain implicit, including what is a good academic practice or a good scholar, and how researchers at different career stages (doctoral candidates, young scholars, senior scholars, professors and others) "make do" (de Certeau, 1984) in spaces defined by existing academic conventions, or in other words try to survive and accomplish the everyday working life in academia. From our reading of transformative food studies, we see explicit considerations of how to bridge the gap between "research" and "practice" but we see a dearth of writing that opens up the different issues influencing, driving and/or discouraging the production of academic knowledge. Manifestations of academic knowledge production include, among other things, research publications, teaching and advising, practical engagement, popular publications, and engagement in societal and political discussions.

In the following, we introduce a practice theoretical approach to academic knowledge production, with the aim of shifting the focus of analysis from transformational food studies to the academic practices that produce this knowledge.

\section{PRACTICE THEORETICAL APPROACH TO ACADEMIC KNOWLEDGE PRODUCTION}

\section{Turning to Practice}

Central to the practice theoretical approach is an ontoepistemological premise that the social is situated in practices (materially mediated action) that also form the locus of knowing (Bourdieu, 1990). In other words, the practice theoretical 
approach suggests that "knowledge" is intrinsically connected with and produced by doing (knowing how) rather than by possessing (knowing that) (Gherardi, 2000). For instance, knowing that one needs a hammer, wood and a saw to build a fence does not necessarily mean that one knows how to build the fence with these materials in practice.

The practice theoretical approach that we adopt emphasizes the relevance of the context and materiality of practices and suggests that practitioners (c.f. carriers of the practice, Reckwitz, 2002) are the experts of their own practice (Räsänen, 2015). In this view, practices, as the objects of study, form what Nicolini (2011) calls "the sites" of knowing within which "we engage with the world and the material and linguistic practices into which we are socialized [and which] provide a background for understanding what counts as an object of knowledge, what counts as knowing subjects, and in the event what counts as possible (and "real")" (Nicolini, 2011, 604). In other words, people acquire embodied knowledge and understandings of what is collectively held as good and appropriate by participating in the same practice with other practitioners.

At its best, then, the practice theoretical approach allows scholars to be reflective with regard to how practices, such as academic research practices, are collectively accomplished (Räsänen, 2008, 2009). The practice theoretical approach extends beyond a collection of theories by providing methodological guidance into studying practices (Miettinen et al., 2009; Nicolini, 2012). However, even though practice theoretical scholarship is equipped with methodological tools and guidance on how to study (other peoples') practices (see e.g., Nicolini, 2009, 2012; Gherardi, 2012), in this article we do not seek to turn (researchers) to the practice of the researched, but advocate that researchers turn to examining their own practice (for debates in feminist and postcolonial theorizing related to knowledge production suggesting similar self-reflection of scientists' work, see e.g., Harding, 2008; Stengers, 2017). For this task, we turn to and introduce one specific practice theoretical framework, namely the framework of practical activity.

\section{Framework of Practical Activity}

Developed by a research group within our (former) local academic community, the framework of practical activity (FPA) (Räsänen and Mäntylä, 2001; Räsänen, 2008, 2009, 2015; Räsänen and Trux, 2012) is the result of an effort to develop "an alternative, constructive, and participatory approach to higher education research" (Räsänen, 2008, p. 2). Acknowledging the diverse disciplinary traditions behind practice theories and drawing on the work of several known scholars (e.g., Pierre Bourdieu, Michel de Certeau, Alasdair MacIntyre and Dorothy Holland), FPA aims to direct people-be they researchers, citizens, businesspeople, artists, food activists, or other practitioners-to their own and/or others' practices. To do this, FPA introduces four different questions that people need to deal with or resolve, implicitly or explicitly, when they engage in any kind of practice. The first one is tactical (de Certeau, 1984) and asks how to do it, which points to the concrete everyday tasks of doing and coping in places and situations often predefined by the conventions and materialities of the (institutionalized) practice in question. The second question is political (Bourdieu, 1990), asking what to accomplish by doing it, and points toward the goals and interests that people have in participating in a (particular) practice. The third question is moral (MacIntyre, 1985): why do it in this way, which directs reflection to what people consider good or bad, right or wrong, and justifiable or not, in the context of the practice in question. Lastly, one faces an identity-related (Holland and Lave, 2009) question of who to be(come) while doing this in this way.

The framework assumes that one or some of these questions are more important than others, depending on the researcher. For example, in their analysis of three units in three different institutions, Räsänen and Mäntylä (2001) developed four potential integrative identities in a business school: (concerned) social scientist, (multi-skilled) business academic, academic specialist and (participatory) action researcher. Concerned social scientists conduct critical and autonomous research that forms the basis for their teaching. Academic specialists focus on a sub-field and use their expertise in publishing and acquiring funding. Multi-skilled business academics get excited about being involved with various activities that might not relate to one another. Participatory action researchers combine "in all activities the moral commitment of a social scientist with the practical skills of a facilitator and change agent" (Räsänen and Mäntylä, 2001, p. 308). Later on, Räsänen added the identity of a feminist researcher to describe one potential research orientation (Räsänen, 2008). Moreover, in some situations the questions of FPA may conflict with each other, and resolving them in a meaningful manner might not be possible. For example, while a researcher with an identity of a (concerned) social scientist might try to be critical when they are teaching, publishing, supervising and doing administrative work, because of their own political and moral orientation, they might not be able to do so in practice. According to Räsänen (2008), praxis refers to intentional reflection on all four questions of practical activity and working from that understanding together with others in order to create a space for meaningful work, though this might prove challenging in contemporary academia.

Thus, while enabling scholars to mobilize these questions through their research designs in order to better understand practices from the lived experiences of the practitioners, FPA also makes visible how knowledge production is inseparable from how a researcher engages in a particular research practice (tactics of research), what the researcher strives for (politics of research), and why they conduct research in particular ways (morals of research). Finally, there is the question of who the researcher is (becoming) (subjects of research) and how they relate to categories, such as doctoral candidate, academic, scholar, scientist, professional, professor, activist, expert, or something else. FPA does not provide a map on how to do research, but it provides a tool or a perspective on how to unpack what one does as a researcher. Furthermore, FPA allows researchers to reflect on the relationship between their own practice and the practices they research, and become more aware of their own research designs, actions and choices related to, for instance (not), applying particular frameworks, committing to certain methods, or (re)presenting findings. 


\section{AN OVERVIEW OF OUR FIELDWORK IN THE CONTEXT OF SELF-RELIANT FOOD PRODUCTION AND PROCUREMENT}

In this article, we draw on our experiences in working in academia and conducting ethnographic studies in the context of self-reliant food production and procurement (Houtbeckers, 2018; Kallio, 2018, 2020; Houtbeckers and Kallio, 2019). We started our academic careers in the late 2000's in the Department of Management Studies in the former Helsinki School of Economics. Since then our institution has been merged with two others, and we defended our dissertations in Aalto University. Throughout our time in the Department of Management Studies, we took part in groups that discussed academic work practices and practice theories. One of these continues to gather as a peer-to-peer group on the premises of the University of Helsinki.

We have conducted ethnographic fieldwork in three different settings: households participating in food collectives and smallholdings operating in the field of regenerative agriculture (Kallio) and households striving for self-sufficiency (Houtbeckers). Taken together, we locate these research settings within the context of transformative food studies discussed earlier, and we refer specifically to self-reliant food production and procurement, because the practices that we have studied are not supported by the dominant ways of doing or talking about food production and procurement in Finland. Practitioners who engage in self-reliant food production and procurement have various motivations, but many of them are concerned about the unsustainability of, and injustices within, the dominant (food) economy. Hence the practitioners navigate between established practices related to food production and procurement, such as avoiding shopping at supermarkets or ordering seeds outside officially approved seed catalogs. But instead of waiting for institutional support, they find it easier, or at times the only option, to be self-reliant and organize independently and/or collectively at grassroots level without asking for permission.

The ethnographic fieldwork on food collectives by Kallio was performed between 2010 and 2017. Food collectives are communities of households that procure food directly from farmers and other producers and distribute it among the participating members. The household members who were most active in founding food collectives were primarily women, whose ages and occupations varied greatly. The materials were generated from 22 food collectives across Finland, and as part of these ethnographic efforts, Kallio served as a member of various food collectives for several years. The data generated as part of the initial study was based on participatory and non-participatory observations, ethnographic (Heyl, 2011) and open-ended narrative/thematic interviews (Riessman, 2008), and archival materials.

The fieldwork on self-sufficient households by Houtbeckers is part of a larger ethnographic study on the role of work in the transformation of societies after the economic growth paradigm in the global North. The fieldwork was initiated in 2016 and remained ongoing when this article was written. As part of the ethnographic study, the researcher participated as a degrowth activist and researcher in various events where the author met members of households striving for self-sufficiency, with whom she conversed about everyday questions in their efforts to reach self-sufficiency. In addition, the researchers spent time in these households. The study also monitors other processes, such as the establishment of an adult learning center for self-sufficiency. This manuscript uses the materials collected from visits to three different households, two of which are located in Southern Finland and one in Eastern Finland. The researcher visited each household one to five times and recorded her observations in fieldnotes. In addition, the researcher produced visual materials and conducted recorded and ethnographic interviews.

The study on smallholdings by Kallio draws equally on ethnographic fieldwork that started in 2019 and continues at the time of writing this article, with the primary source of data being participant observation. Kallio has participated in the daily work of six different farms and visited several other farms for a day each to observe their activities. In addition to ad-hoc interviews during the fieldwork, the researcher conducted video interviews with the farmers to make visible the process of interviewing. In this article, the author reflects on the experiences of balancing between the pressure to conduct formal interviews and continuing the fieldwork by only participating and observing.

While our ethnographic fieldwork is geared toward practice theoretical understanding, the processes have not been straightforward. For instance, food practices are connected to and mediated by material infrastructures, societal rhythms and political discourses and decision-making (Houtbeckers and Kallio, 2019). As a result, our fieldwork has allowed us to see the tension that arises from the methods and theoretical and conceptual frameworks we applied and the disciplinary fields to which we are contributing. In the following, we illustrate some of the key tensions by reporting on instances in which the expectations we faced, as scholars in the discipline of organization studies, were at odds with our own political, moral and subjective understandings and were reflected in our tactical moves with which we navigated the domains of transformative food studies, organization studies scholarship, and the (empirical) field of self-reliant production and procurement.

\section{MAKING ACADEMIC KNOWLEDGE PRODUCTION VISIBLE: VIGNETTES ON RESEARCH(ING) PRACTICE}

To bring the reader closer to our own research practice, we use vignettes. In the style of Spalding and Phillips (2007), we seek to make our own research practice accessible to readers and use vignettes for what we call "reflective description" of our own experiences as researchers and activists also working in academia. This type of application differs from what vignettes are more commonly used for, namely as a technique for producing data, in that we aim to direct attention to our own research practices and make the presence of the researcher as a producer of knowledge visible rather than to produce or represent data through the vignettes. 
Each of the following vignettes draws attention to specific challenges that we have faced during, before or after our field work. Taken together, they speak of our tactical moves, political pursuits, moral concerns, and identity formation more generally.

\section{Does It Matter What We Call "It"?}

Galina: I ended up researching food collectives almost by accident. My research began from an observation that, despite the prevailing public discourse pointing to "good quality food" and "all-encompassing selection" in supermarkets, several people seemed to disagree. Instead, many faced difficulties in finding organically and locally-produced food in their nearby stores, or even information on the origin of their food and how it was produced. I became interested in how and why people chose to go directly to the sources of their food.

I encountered food collectives at the beginning of 2010, when I interviewed a person who was active in the first emerging community of urban farming in Finland. At the time, it was almost impossible to track food collectives. In Finland this activity was only starting to emerge and no catalogs or websites for more information on these groups existed, as the vast majority of food collectives were informally organized and very locally situated households. Hence I decided to participate in food collective activity, so that I could meet the people who were active in these local groups and learn more about household food collectives.

The more I got to know the food collectives, the more confused I became: no matter how eagerly I looked for relevant concepts, frameworks, and analytical categories in the vast amount of literature I was reading, what I encountered did not resonate with my own fieldwork. Food collectives appeared more diverse, less political, and non-institutionalized compared to other descriptions of similar phenomena. I observed that food collectives included families with children as well as singleperson households, grandmas and students, representatives of the upper middle class and low-income single parents. Some had good jobs, while others were struggling financially. Some were against nuclear power, while others were proponents of it. Some loved meat while others eschewed it. What kind of food was ordered, how often, and from which kind of farmers or suppliers also varied among the groups. On top of all this, every collective had distinctly creative distribution points, payment and ordering systems, and distribution practices that often seemed to defy food-related laws and regulations. For example, more than once I participated in pouring raw milk from large containers into people's own bottles, or waited for a fisherman to bring his catch that he had fileted directly on ice instead of a processing facility.

When discussing my observations with more senior scholars in my academic community, or presenting my research at various seminars and international conferences, I was subtly offered conceptualizations of the phenomenon and commonly guided toward such frameworks as social movements, (moral) markets, fields, alternative organizing and sustainable consumption. In retrospect, I chose to conceptualize food collective activity as selfreliant food procurement. While for me this was an empirically grounded concept that captured the "wild" nature of food collective organizations, it was not a conceptualization that came from the research participants. Rather, this concept allowed me as a researcher to participate in academic and public discussions about various understandings of the economy and engage in reflecting on the concepts that I was often directed to.

Eeva: The conceptualization of self-sufficient households has been equally challenging for me. Everyday practices of citizens that enable or disable sustainability transformations are often categorized in the spheres of energy, housing, mobility and food (see e.g., Robertson, 2014). While it makes sense to limit the scope of research and target policy measures, everyday practices escape such categorizations. When I have visited households striving for self-sufficiency, the initial focus was on food or food-related jobs. This is explained by the stark contrast between the everyday life that these households experience compared to households that bear little or no responsibility for growing their own food. In households striving for self-sufficiency, the growth and rest seasons of plants define when work is to be done at home or what should be collected from the forest.

In contrast to office work during weekdays from 9 to 5 all year around, growing food is connected to biological rhythms and seasons, winter being the calmest time of the year. People grow seedlings in the spring, do outdoor farming in the summer, and preserve food and harvest in the autumn. The end of summer and autumn is also spent collecting berries and mushrooms in the forest. Winter resting season usually lasts from December to February, during which the household plans the coming growing season and possibly places orders for new seeds. Overall, the food cultivation habits of self-sufficient households are often very diverse, as they buy only a limited amount of food from grocery shops. The households must also estimate the amount of work that each crop will require: some varieties produce very little in relation to the effort that is spent cultivating them, and/or they may be susceptible to pests. Excess harvest of one produce is exchanged with neighbors for products the household still needs.

All these practices directly related to food cultivation link to energy, housing, and mobility practices, since in most households one or all members also have regular duties outside the property, such as wage labor or school. While a household could in theory be self-sufficient in food, it might depend on fossil fuels for heating, electricity, and transport. Therefore, practitioners refrain from talking about self-sufficiency as an either/or status, but rather refer to "striving for self-sufficiency," which reflects a degree of self-sufficiency. This highlights self-sufficiency as an existential process, rather than a rational question of resources (Salminen, 2016). While the variation in the degree of selfsufficiency is evident when living in such a household, some scholars hang on to this particular matter when they comment on my presentations or texts. Moreover, for some the concept of self-sufficiency relates to isolation and even xenophobia (see e.g., Gorostiza, 2019). While such conceptual analysis is needed, I decided to use self-sufficiency because this is a concept used by the practitioners. Does it matter what we as scholars call a household that wants to grow most of the food they eat? What do the categories used reveal and hide? 


\section{How and Whether to Interview (at All)?}

Galina: As I started my fieldwork among small-scale farmers who were working toward regenerating the local ecosystem, I soon realized that conducting interviews felt artificial and inappropriate: I wanted to know what to ask before asking what I didn't know about. So I went and worked at the farms, fed the animals, sowed hundreds of seeds, did hours of weeding, learned how to braid onions, steal eggs from the chicken (to use the words of the participants) and shovel manure for the compost. I worked alongside farmers, local volunteers, WWOOFers ${ }^{1}$ and trainees. I would listen to people's stories, cook lunches in farm kitchens, get lost in translating agricultural vocabulary and farm jargon, and feel overwhelmed by the amount of care and work that the farmers dedicated to their soil, animals and the surrounding people.

Eeva: I feel exactly the same. Instead of visiting a household striving for self-sufficiency with an interview protocol, I volunteered to work for them. Usually, I knew the members of the households before my visit since we had attended a gathering together, or they were acquaintances through activist networks. Paradoxically, interviews seemed a more suitable genre of interaction when I visited a new household. During these visits, the interview seemed an approaching performance that all of us anticipated, when in fact everything beyond the interview was as informative in obtaining a sensory experience of a household and its everyday practices. After one nice and relaxed recorded interview in a new household, one of the participants asked, "Why didn't you ask why?" At first I did not understand what they meant. They explained that I had not asked them why they engage in self-sufficiency. I admitted that this was correct, and replied that, according to my previous experience with microentrepreneurs, people whose lifestyle attracts attention learn an "elevator pitch" that they seem to offer to many, including researchers. In my experience, instead of reflecting on their motivations, such talk tends to reflect cultural expectations. During this particular interview, I turned my recorder on again and asked, "Why do you do all this?" and let them answer.

Galina: I can relate to your experiences very well. When, after a year of doing fieldwork, I eventually decided to conduct interviews with the farmers, I invited them to design the interviews together with me. I asked: "What would you like to talk about?" and "What do you consider important and want to tell others?" I also shared with them what interests me and why. For instance, I wanted to know how farmers understand "regenerative agriculture" and how they see this concept manifesting in and through their work in practice. We had deep and engaging conversations about the meanings and understanding of farmers about their own work. But while we designed the interviews together in a dialogue with farmers, which itself became a kind of mutual interview, when the "actual" interview started, I noticed that some farmers tried to anticipate what I (as a researcher belonging to an academic community), political decision makers, or the broader public would want to hear. The conversations we had and the silent moments,

\footnotetext{
${ }^{1}$ Farmers use the word "WWOOFers" to refer to those volunteers who come to work at the farms through the World Wide Opportunities on Organic Farms (WWOOF) network.
}

laughter and tears we shared in the fields felt much more informative and genuine than the recorded interviews. As my research continues, I notice myself asking, silently, over and over again, why interview at all, if it cannot capture the emotions, and the embodied ways of knowing and relating to the soils, other-than-humans, and the local people?

\section{Submit, Revise, and Resubmit}

Eeva: For me the questions about the concepts and research methods used culminate in submission and review processes. In one manuscript I wrote that my fieldwork has revealed a phenomenon that I refer to as households striving for selfsufficiency, because that is what the practitioners use. One editor questioned that my fieldwork would reveal a phenomenon, as it was there to be found, but instead suggested that the phenomenon would be the starting point of my research. While I agree that researchers construct phenomena rather than finding them, to me a revelation was exactly what took place: while I was tracing various locations of transformative livelihood practices, these households that related to self-sufficiency seemed to be glorified as pioneers or bypassed as a marginal hobbyist lifestyle. While it is not always important nor possible to report researcher's every step in detail and in chronological order, this particular step seemed important, since it reflected my path to the phenomenon. I did not begin my research by focusing on these households, but I did not want to ignore them either. While the wording may seem insignificant, writing about research processes can also hide what has actually happened.

Galina: I completely understand your fascination with the meaning of words. How to communicate and report on my research to other scholars appears challenging at times. One good example is answering a call for submission to a conference or special issue. If I know the conveners, it is easier to "submit from the heart" and articulate one's argument in relation to my observations and intuition. However, in my experience there are often various issues at play in formulating the submission. It is a question of choosing conceptualizations that secure my place amongst the submissions while helping me to strive toward what I want to accomplish in relation to the call at that moment. Sometimes I attend conferences because I need a deadline to work on an argument, while at other times, I want to discuss my early observations from the field. Sometimes, when I communicate my research to other scholars, I notice myself wanting to associate with them, but sometimes, on the contrary, I feel I have nothing in common with them. This is specifically visible in studying transformative food systems as I do not identify myself as a "food scholar" who associates with the empirical context (see also Figueroa, 2015), or a "practice scholar" who associates with developing a particular theoretical framework. Rather, I see myself as a critical organization scholar who is driven by the will to trace the root causes of the ecological crises and challenge conceptualizations and practices supporting extractive ways of living-including those within academia.

Eeva: This reminds me of private discussions that I have had with scholars from different disciplines who have more stable positions in academia. When I have approached them to discuss the topics we share, they have asked quite promptly where I see myself in academia in the future and/or where I would like to 
publish. I find this surprising, since my career plans have little to do with understanding a phenomenon or analyzing research materials. While I understand that the chosen academic audience dictates what results are interesting to publishing and which concepts are relevant, I have come to accept that rich discussions about content are most likely to happen with scholars who do similar work or have similar orientations to academic work.

The vignettes above show the variety of instances of academic practices that we faced during our studies and the decisions we made, did not make, or should have made. The vignettes also reveal how, when engaging in knowledge production, one cannot wipe the researcher out: there is always the one who is studying and those who are being studied. All the choices mentioned above appear within the disciplinary context in which the researcher is embedded. Thus, instead of simply asking how the "researched" practitioners can help the researchers to produce more and better knowledge about them and their world, it is equally important to ask how researchers can better understand their own practice and improve it from the perspectives of their moral understandings, political interests, and tactical possibilities while pursuing their identities. This shift is extremely important as it sheds light on scholarly practice and its embeddedness in knowledge production, a practice usually taken for granted as something disinterested, neutral, and objective by nature (see e.g., Harding, 2008).

\section{OPENING UP ACADEMIC KNOWLEDGE PRODUCTION IN THE CONTEXT OF TRANSFORMATIVE FOOD STUDIES}

In this section we focus on the first question we set for this paper and explore how researchers can make their own academic practice and knowledge production more explicit, and improve their own academic practices in the context of transformative food studies. We return to the framework of practical activity (FPA) to answer this question and make explicit the tactics, politics, morals and subjects in academic research practice (Räsänen, 2008). We draw on examples from our own experiences as introduced in the vignettes, and from our analytical reading of the transformative food studies literature. We do not consider these examples to exhaust the possibilities in transformative food studies. Rather, we hope that these examples help to explicate the potential of FPA and evoke further discussion.

\section{The Politics in Transformative Food Studies}

Academic research practice, and science in general, carries the expectation of objectivity (Stengers, 2017). It is not uncommon for researchers, even within transformative food studies, to fear that they are marked, or labeled, as "activists" (Croog et al., 2018). Yet, it seems to us that pursuing transformation together with the people participating in the study through, e.g., scholar-activist praxis (Wakefield, 2007; Routledge and Derickson, 2015; Croog et al., 2018) is what many scholars within transformative food studies aim at-either implicitly or explicitly.

However, researchers are equally likely to have other interests extending beyond the pursuit of practical relevance. Some may strive to produce "new," "more," or "better" knowledge, e.g., in climate research or soil science, while others may be driven by academic publishing games (Bourdieu, 1990) and by pursuing power through climbing up the tenure track ladder. In our case, the vignettes reveal how we have struggled between the requirements pushing us toward "playing the game" (see also Houtbeckers, 2019; Kallio, 2019), but also how we have consciously chosen to do otherwise by committing to the kind of academic practice that tries to reflect on the underlying politics of knowledge production. This is manifested in, for instance, how we have sought to understand the phenomena under study from the perspectives of the people studied and by taking the practitioners' experiences seriously (see also Houtbeckers and Kallio, 2019) rather than from (only or primarily) pursuing academic interests. The conceptual struggles we have had with choosing "the right" or "most appropriate" way to frame our research have been inherently political, in which we have been directed toward publishing in high impact journals that host discussions around very specific theoretical frameworks, which we understand as "gap spotting" (Alvesson and Sandberg, 2013).

For example, the use of self-reliant food production and procurement as a reference to the phenomena that we study has been a conscious and a political choice: we have pursued a concept that is as close to the ground as possible and truthful to our observations. But, as acknowledged by other scholars (Goodman et al., 2011; Figueroa, 2015; Croog et al., 2018), while all conceptualizations entail political interests, they tend to remain hidden. By choosing a concept that is not commonly used in ongoing academic discussions, we often need to adapt to different concepts that each carry their own histories and meanings in order to connect our research to the broader, globally recognized phenomenon, i.e., of building local, resilient and regenerative food systems, and to speak to other scholars about our research. This usually means applying a more general terminology, such as transformative food studies, local food economies, regenerative agriculture and the like, when speaking of initiatives like self-reliant food production and procurement. These all entail political assumptions about what it is that people pursue when participating in these initiatives and what it is that the researchers seek to achieve by using those particular concepts. Similarly, our amalgamated concept of transformative food studies is political. While we find it important to form a conceptual overview of various food studies that relate to more sustainable, ecological, fair, diverse, and locally distinctive societies, not everyone taking part in the debates might feel the same.

While associating ourselves with the underlying pursuit of transformative food studies, that is to make our own research more relevant for and truthful to the experiences of the people who participate in local food initiatives, we are also driven to transform academia. For us, knowledge production is inherently political, and not least because of the nature of academic research practice. Just as it is important to make visible various political visions in research domains like transformative food studies, it is important for us to discuss them in relation to, e.g., organization studies (business), management and economics, which are disciplines close to our formal education. For instance, one may ask: what pursuits 
and justifications drive sustainability transitions? Are they framed through discourses and conceptualizations of innovation, entrepreneurship, employment, economic growth, degrowth, community economies, interspecies solidarity, care work, or something else? Thus, we advocate that scholars participate in more explicit articulations of their own pursuits-whether they themselves consider them to be of a "political" nature or not.

\section{The Morals in Transformative Food Studies}

Examining the moral aspects in transformative food studies directs us to reflect on why researchers study phenomena concerning food in certain ways, and what sort of knowledge production they consider to be good and justifiable. In our experience, many of the grassroots activities that aim to combat climate change and ecological crises by reorganizing food systems are emergent, and thus remain invisible in statistics and archives. This tendency makes it hard to obtain data, especially with methods developed for measuring rather than observing. But while a qualitative research approach is particularly suited to studying such phenomena (Granqvist et al., 2017), it is rarely neutral and value-free (Figueroa, 2015; Croog et al., 2018).

Designing research in the context of food justice or food sovereignty research, usually along the lines of scholar-activism, means being reflective about the possibility of the emergence of unequal power relations, collisions between the needs and interests of the researchers and those of the researched, the challenges of building more just and sustainable food systems, and the appearance of various emotions during the fieldwork, among other things (Routledge and Derickson, 2015; Croog et al., 2018; Reynolds et al., 2018). Acknowledging these issues seems to form the underlying moral understanding of what is, or is not, a good research practice in the context of transformative food studies.

These understandings, in turn, influence how research is conducted and why certain methods seem to be better for knowledge production than others. For instance, Derickson and Routledge (2015, p. 6) make a moral statement by saying that "theoretical inquiry must always be accountable to rather than distant from actually existing community-based activism." In practice, we have observed (as reported in the studies published) that this means using participatory methods and often assumes mobilizing action research approach; these are considered good ways to (co)produce knowledge. Some scholars have urged researchers to articulate their values explicitly or design their research according to specific values (Levkoe et al., 2019), but often these issues remain implicit to other scholars.

In our vignettes, we have described how, when engaging in participant observation, we have encountered moments in which something does not feel right, or good (e.g., conducting interviews, asking certain questions), and when something does feel right and good (e.g., sharing work silently, getting emotional together). Indeed, while tracing morals in action (Hansen, 1998) often appears a challenging task, emotions can enable researchers to examine and reveal moral stances (Zigon, 2009). Therefore, reflecting on the emotions that researchers face not only during fieldwork, but also when participating in everyday practices in their own academic communities, and possibly even finding ways to do this collectively, allows scholars to better understand how knowledge production is always also a moral act and connected to what feels good or bad, right or wrong, justifiable or not.

\section{The Tactics in Transformative Food Studies}

The transformative food studies articles that we have referred to in this article focus more on the politics of research or researchers' identity than on how to do research and produce knowledge in practice, i.e., tactics. According to de Certeau (1984), tactics is about the ability to (try to) accomplish things when one has little or no room to act or has to act in a space owned by others. As a result, people cannot dictate the rules of the game, but need to "make do" with what they have. With the FPA, we have illustrated some situations that scholars face in organization studies, but these are not limited to this academic context only. In the domain of transformative food studies, Routledge and Derickson (2015, p. 395) describe how "[a]cademic institutional structures are increasingly neoliberal in outlook and operation, which vitiates radical practice, and even radical writing." Their tactics included pursuing their scholarly activism with small grants on topics they found important.

As described in our vignettes, we have also made tactical moves by using a particular concept, for instance, when applying for funding or when submitting an abstract to a conference. While we need to justify our choices conceptually, we have rarely been open about the tactics of our actions. All tactical choices might not be interesting to report, but sometimes everything culminates in focusing on how to do this, especially when the space for action has diminished for one reason or another (Räsänen, 2008). For instance, for us as organizational scholars it has not been straightforward to access relevant discussions that take place in the domain of transformative food studies or other transdisciplinary debates without the financial support that enables us to participate in these events. Especially when an accepted conference presentation is required to obtain a specific travel grant, we need to first secure our admittance by using the given concepts.

Tactics that researchers apply may equally manifest in their fieldwork, during which unplanned situations, such as an unexpected counter-question from a participant, are likely to occur. As a result, we as researchers have to deal with them as they arise. But employing tactics on the field is not limited to the unpredictable, but also to the fact that observing everything at the same time is impossible, and thus choices have to be made regarding what one participates in, where and when, or how one interacts and asks questions in an interview. When it comes to researchers' mundane choices and reflections on their tactics of coping, we cannot know them unless the researchers report them. In our experience, informal practices such as lunches and coffee/tea breaks, or social events at conferences, may be more open platforms for reflecting on the possibilities and impossibilities of researchers.

How do we act upon our interests, according to our identity, and be truthful to our moral understandings? We believe that formalizing discussions on such questions would be important to bring the tactics of researchers into the daylight and make the mundane struggles of researchers more visible. This in turn can have positive consequences for transformative food scholars who struggle between scholarship and activism (Wakefield, 2007; 
Derickson and Routledge, 2015; Croog et al., 2018; Reynolds et al., 2018).

\section{The Subjects in Transformative Food Studies}

Finally, the FPA directs us to the question of who to be(come) when doing research in a particular way. In transformative food studies, the question of identity or subjectivity arises in recent discussions about balancing between being a scholar, an activist and/or combining them into the identity of a scholar-activist (Derickson and Routledge, 2015; Routledge and Derickson, 2015; Croog et al., 2018; Reynolds et al., 2018). For the latter, what does it mean for a person, their emotional worlds and habitus (Bourdieu, 1990), to combine these pursuits in practice?

Our experience is that balancing between being a scholar and caring for the people whose lives we participate in is emotionally both rewarding and consuming. We are both active in grassroots movements related to our ethnographic fieldwork and will most likely continue to be active when our academically-oriented fieldwork is over. Reflecting on our own position, we feel more confident in our postdoctoral status to write this paper compared to the status of doctoral candidates, when we felt more fragile and uncertain combining scholarship and activism, despite already operating in similar ways.

Our reading of transformative food studies literature has made us reflect on the multiple identities and possibilities for a researcher in this domain. Several studies speak for activist research assuming scholars to take an active part in concrete initiatives and in being conscious about their knowledge production (Derickson and Routledge, 2015; Figueroa, 2015; Croog et al., 2018; Levkoe et al., 2019). For example, we find the autoethnographic account of (Levkoe et al., 2019) fascinating, but it falls short on the differences among the researcher-subjects involved. What does it actually mean to be a scholar-activist in the sphere of transformative food studies? We interpret that researchers in the domain of transformative food studies are expected to be oriented toward the practices that they study and to take an active part in the activities of the researched, but it remains unclear to us whether other possibilities exist. When scholarly activism in the context of transformative food studies seems to include digging the soil and getting one's hands dirty, what other opportunities are there to be a researching subject and contribute to transformative food studies?

\section{CONCLUSIONS}

In this paper we asked how to make our own academic knowledge production/research practice more explicit and why it is important to do this in the context of transformative food studies. We provided answers to the first question in the previous section, applying the framework of practical activity (FPA) to research in the context of transformative food studies, and now we turn to the second question.

Transformative food studies, as a nexus for various debates on how to make food systems more sustainable, includes research from various disciplines. It seems that meaningful debates are being carried out with several concepts, such as food sovereignty, food citizenship and alternative food networks, and in various disciplinary communities, but these debates may be isolated from one another. When people come together, as is the case with this special issue, it takes time to form a common ground for discussion. Moreover, there is understandable friction between disciplinary assumptions. We suggest that this can be facilitated by focusing on academic research as a practical activity, along the lines of FPA: how has something been studied, what have the scholars been aiming at, why it has been studied in certain ways, and what does a (group of) scholar(s) become through the activity. We claim that sharing this type of academic knowledge helps to better understand the processes and the outcomes of the studies in question and assist scholars in reflecting upon their own knowledge production, while also making it easier for outsiders to discuss and understand these practices and the choices made.

As the researcher is never an empty canvas, we suggest that it is extremely useful for academic scholarship, here in the domain of transformative food studies, to strive toward greater openness. We believe that transformative food studies would benefit from opening up the practice of academic knowledge production, as pointed out by several scholars (Delind, 2006; Wakefield, 2007; Starr, 2010; Alkon and Mares, 2012; Jehlička et al., 2020). There is a clear danger that powerful frameworks and conceptualizations of food practices such as, for instance, social movements and the creation of markets (Weber et al., 2008; Starr, 2010; Kurland and McCaffrey, 2016), end up dominating how the various grassroots phenomena around food are represented and (mis)interpreted (Kallio, Delind, 2006). Equally, in applying supposedly transformative concepts, such as food deserts, alternative food networks and ecosystem services, and aiming to reveal problems in the conventional agri-business regime or emphasize the potential of local food systems, there is a danger of reproducing the dominant-colonial, Western, capitalist, neoliberal, white, masculine-understandings of transformation. Examples of these include understanding people as "deficits" in food deserts discourse (Figueroa, 2015) or focusing on how ecosystems can serve people (Zhang et al., 2007) instead of how people can serve ecosystems.

Our experience is that openness and transparency is often required for more technical issues, including validating the methods applied, the research referenced, and the frameworks introduced. But due to academic conventions, researchers might not be asked to reflect on how their studies may be linked to what is tactically possible, politically desirable, morally justified, and attractive for the researcher identity-wise.

The need to open up academic knowledge production as practical activity goes beyond transformative food studies. Given the pressure to adapt to, and in the best case to impact, the vicious socio-ecological crises, relying on science and research seems like a safe bet. However, more knowledge and better facts might not help us (Latour, 2018). Thus, we suggest that knowledge production in academic research practices is reflected on in order to create the sustainability transformations that are mindful of their connections to the ways of thinking that led to the complex set of crises in the first place.

The framework of practical activity offers one tool for such endeavors. We do not claim that researchers are not already doing this in places where it is safe. Rather, we, together with 
several other scholars (Räsänen, 2008, 2009; Stengers, 2017; Parker, 2018), claim that contemporary academic practices do not support revealing such work. Moreover, academic praxis that supports such work is under a constant threat of dissolution due to, e.g., applying the ideas of new public management in academia (Räsänen, 2008). In fact, instead of reporting their positionality, researchers can have many good reasons to hide rather than reveal their reflections. Yet we would like to see more such texts and analyses of scholars' work. When it comes to researchers' choices and reflections about their research practice, we simply cannot know them unless the researchers report them.

While some might say that reflecting on academic research practices is useless, we propose that it offers an important understanding not only of a phenomenon, but also of the academic research practice that governs how knowledge is produced. Instead of simply asking how the "researched" practitioners can help the researchers to produce more and better knowledge about them and their world (see, e.g., this special issue call), it is equally important to ask how researchers can better understand their own research practice. In these times of mounting socio-ecological crises and complex issues, it is worth asking why we need more, or better knowledge and what kind of knowledge we need. What if, instead of producing more certainty through more knowledge, we need research to reveal more uncertainty through more sensitive and situated ways of knowing (see e.g., Kimmerer, 2013; de la Bellacasa, 2016)? Specifically, when searching for solutions to wicked problems, the answer may well be to go to the roots of the academic research practice

\section{REFERENCES}

Alkon, A. H., and Mares, T. M. (2012). Food sovereignty in US food movements: radical visions and neoliberal constraints. Agric. Hum. Values 29, 347-359. doi: $10.1007 / \mathrm{s} 10460-012-9356-\mathrm{z}$

Allen, P. (2010). Realizing justice in local food systems. Cambridge J. Regions Econo. Soc. 3, 295-308. doi: 10.1093/cjres/rsq015

Alvesson, M., and Sandberg, J. (2013). Constructing Research Questions: Doing Interesting Research. London: SAGE. doi: 10.4135/9781446270035

Barad, K. (2003). Posthumanist performativity: toward an understanding of how matter comes to matter. Signs 28, 801-831. doi: 10.1086/345321

Böhm, S., Spierenburg, M., and Lang, T. (2020). Fruits of our labour: work and organisation in the global food system. Organization 27, 195-212. doi: 10.1177/1350508419888901

Bourdieu, P. (1990). The Logic of Practice. Stanford, CA: Stanford University Press.

Briner, R. B., and Sturdy, A. (2008). Introduction to food, work and organization. Hum. Relat. 61, 907-912. doi: 10.1177/0018726708093901

Callon, M. (1984). Some elements of a sociology of translation: domestication of the scallops and the fishermen of St Brieuc bay. Sociol. Rev. 32, 196-233. doi: 10.1111/j.1467-954X.1984.tb00113.x

Conde, M. (2014). Activism mobilising science. Ecol. Econ. 105, 67-77. doi: 10.1016/j.ecolecon.2014.05.012

Croidieu, G., den Hond, F., Moser, C., Reinecke, J., and Svejenova, S. (2017). Call for Papers on a Special Issue on: Food Organizing Matters: Paradoxes, Problems and Potentialities. Organization Studies. Available at: https://journals. sagepub.com/pb-assets/cmscontent/OSS/CFP\%20SI\%20Food\%20Organizing \%20Matters_CM_GC_JR_SS_fdh.pdf.

Croog, R., Hayes-Conroy, A., Gutierrez-Velez, V. H., and Saenz Montoya, A. (2018). Real world food justice and the enigma of the scholar-activist label: a reflection on research values. ACME 17, 1024-1044.

de Certeau, M. (1984). The Practice of Everyday Life. Berkley: University of California Press.

de la Bellacasa, M. P. (2016). "Ecological thinking, material spirituality, and the poetics of infrastructure," in Boundary Objects and Beyond: Working with and allow reflection on whether these problems can be solved, as Einstein has put it, from the same level of consciousness that created them-or whether they can be resolved at all.

\section{DATA AVAILABILITY STATEMENT}

The original contributions presented in the study are included in the article/supplementary material, further inquiries can be directed to the corresponding author/s.

\section{ETHICS STATEMENT}

Ethical review and approval was not required for the study on human participants in accordance with the local legislation and institutional requirements. The patients/participants provided their written informed consent to participate in this study.

\section{AUTHOR CONTRIBUTIONS}

GK and EH have contributed with an equal amount of work to the manuscript. Both authors contributed to the article and approved the submitted version.

\section{FUNDING}

Our research has been funded by Maj and Tor Nessling Foundation, Kone Foundation, Foundation for Economic Education, and Ministry of Agriculture and Forestry of Finland.

Leigh Star, eds G. C. Bowker, S. Timmermans, A. E. Clarke, and E. Balka (Massachussets, CA: MIT Press).

Delind, L. B. (2006). Of bodies, place, and culture: re-situating local food. J. Agric. Environ. Ethics 19, 121-146. doi: 10.1007/s10806-005-1803-z

DeLind, L. B. (2011). Are local food and the local food movement taking us where we want to go? Or are we hitching our wagons to the wrong stars? Agric. Hum. Values 28, 273-283. doi: 10.1007/s10460-010-9263-0

Derickson, K. D., and Routledge, P. (2015). Resourcing scholar-activism: collaboration, transformation, and the production of knowledge. Prof. Geographer. 67, 1-7. doi: 10.1080/00330124.2014.883958

Eikeland, O., and Nicolini, D. (2011). Turning practically: broadening the horizon. J. Organ. Change Manag. 24, 164-174. doi: 10.1108/09534811111119744

Figueroa, M. (2015). Food sovereignty in everyday life: toward a peoplecentered approach to food systems. Globalizations 12, 498-512. doi: 10.1080/14747731.2015.1005966

Foley, J. A., Ramankutty, N., Brauman, K. A., Cassidy, E. S., Gerber, J. S., Johnston, M., et al. (2011). Solutions for a cultivated planet. Nature 478, 337-342. doi: 10.1038/nature10452

Forssell, S., and Lankoski, L. (2015). The sustainability promise of alternative food networks: an examination through "alternative" characteristics. Agric. Hum. Values 32, 63-75. doi: 10.1007/s10460-014-9516-4

Gherardi, S. (2000). Practice-based theorizing on learning and knowing in organizations. Organization 7, 211-223. doi: 10.1177/135050840072001

Gherardi, S. (2012). How to Conduct a Practice-Based Study: Problems and Methods. Cheltenham: Edward Elgar Publishing Limited. doi: $10.4337 / 9780857933386$

Goodman, D., DuPuis, E. M., and Goodman, M. K. (2011). Alternative Food Networks: Knowledge, Place and Politics. London: Routledge. doi: 10.4324/9780203804520

Gorostiza, S. (2019). “A historical exploration of the 'Autarky' concept," in Towards a Political Economy of Degrowth, eds. E. Chertkovskaya, A. Paulsson, and S. Barca (Lanham: Rowman \& Littlefield Publishers), 209-224.

Granqvist, N., Kallio, G., and Nissilä, H. (2017). "Doing qualitative research on emerging fields and markets," in Routledge Companion to Qualitative Research 
in Organization Studies, eds R. Mir and S. Jain (Routledge: Taylor \& Francis). doi: 10.4324/9781315686103-17

Hansen, D. T. (1998). The moral is in the practice. Teach. Teacher Educ. 14, 643-655. doi: 10.1016/S0742-051X(98)00014-6

Harding, S. (2008). Sciences From Below: Feminisms, Postcolonialities, and Modernities. Durham: Duke University Press. doi: 10.1215/9780822381181

Heyl, B. S. (2011). "Ethnographic interviewing," in Handbook of Ethnography, eds A. Coffey, L. H. Lofland, J. Lofland, P. Atkinson, and S. Delamont (London: SAGE Publications), 369-383.

Holland, D., and Lave, J. (2009). Social practice theory and the historical production of persons. Actio 2, 1-5.

Houtbeckers, E. (2018). Land in transition: the role of land for Finnish households striving for self-sufficiency. Nordia Geogr. Public. 47, 75-84.

Houtbeckers, E. (2019). "Kohtuusajatteluun keskittyvän tutkija-aktivistin kohtuuton työnteko," in Tutkija Toimii Toisin - Esseitä Akateemisesta Työstä ja Sen Vaihtoehdoista Aalto University Publication Series Economy + Business, ed K. Räsänen (Helsinki: Aalto University Publication Series Economy + Business), 347-359.

Houtbeckers, E., and Kallio, G. (2019). Talous käytännönteoreettisesti: kotitalouksien omaehtoinen ruuanhankinta taloutta koskevan tiedon lähteenä. Tiede edistys 150-169.

Jehlička, P., Grīviņš, M., Visser, O., and Balázs, B. (2020). Thinking food like an East European: a critical reflection on the framing of food systems. J. Rural Stud. 76, 286-295. doi: 10.1016/j.jrurstud.2020.04.015

Kallio, G. (2018). The visible hands - an ethnographic inquiry into the emergence of food collectives as a social practice for exchange. Alue Ja Ympäristö 47, 66-71. doi: $10.30663 /$ ay.75942

Kallio, G. (2019). "Katse maassa - tutkijatohtorin orientaatiota etsimässä." in Tutkija toimii toisin - esseitä akateemisesta työstä ja sen vaihtoehdoista Aalto University Publication Series Economy + Business, ed. K. Räsänen (Helsinki: Aalto University Publication Series Economy + Business), 360-382.

Kallio, G. (2020). A carrot isn't a carrot isn't a carrot: tracing value in alternative practices of food exchange. Agric. Human Values. doi: 10.1007/s10460-020-10113-w

Kimmerer, R. W. (2013). Braiding Sweetgrass: Indigenous Wisdom, Scientific Knowledge and the Teachings of Plants. Minneapolis, MN: Milkweed Editions.

Kuhn, T. S. (1970). The Structure of Scientific Revolutions. 2nd Edn. Chicago: University of Chicago Press.

Kurland, N. B., and McCaffrey, S. J. (2016). Social movement organization leaders and the creation of markets for "local" goods. Business Soc. 55, 1017-1058. doi: 10.1177/0007650314549439

Latour, B. (2018). Down to Earth: Politics in the New Climatic Regime. English edition. Cambridge; Medford, MA: Polity.

Levkoe, C. Z. (2011). Towards a transformative food politics. Local Environ. 16, 687-705. doi: 10.1080/13549839.2011.592182

Levkoe, C. Z., Brem-Wilson, J., and Anderson, C. R. (2019). People, power, change: three pillars of a food sovereignty research praxis. J. Peasant Stud. 46, 1389-1412. doi: 10.1080/03066150.2018.1512488

MacIntyre, A. (1985). After Virtue: A Study in Moral Theory. London: Duckworth.

Miettinen, R., Samra-Fredericks, D., and Yanow, D. (2009). Re-turn to practice: an introductory essay. Organ. Stud. 30, 1309-1327. doi: $10.1177 / 0170840609349860$

Nicolini, D. (2009). Articulating practice through the interview to the double. Manag. Learn. 40, 195-212. doi: 10.1177/1350507608101230

Nicolini, D. (2011). Practice as the site of knowing: insights from the field of telemedicine. Organ. Sci. 22, 602-620. doi: 10.1287/orsc.1100.0556

Nicolini, D. (2012). Practice Theory, Work, and Organization: An Introduction. Oxford: Oxford University Press.

OECD (2020). Enhancing Climate Change Mitigation through Agriculture. Available online at: https://www.oecd-ilibrary.org//sites/e9a79226-en/index.h tml?itemId=/content/publication/e9a79226-en\&_csp_=aacad1f745ee37e8ede eff3c378cc507\&itemIGO=oecd\&itemContentType=book\# (accessed June 26, 2020).

Ortner, S. B. (1984). Theory in anthropology since the sixties. Comp. Stud. Soc. Hist. 26, 126-166. doi: 10.1017/S0010417500010811

Parker, M. (2018). Shut Down the Business School. London: Pluto Press; University of Chicago Press Economics Books. doi: 10.2307/j.ctvqhtj8

Patel, R. (2009). Food sovereignty. J. Peasant Stud. 36, 663-706. doi: 10.1080/03066150903143079
Räsänen, K. (2008). Meaningful academic work as praxis in emergence. J. Res. Pract. 4, 1-22. Available online at: http://jrp.icaap.org/index.php/jrp/article/ view/78/102

Räsänen, K. (2009). Understanding academic work as practical activity-and preparing (business-school) academics for praxis? Int. J. Acad. Dev. 14, 185-195. doi: 10.1080/13601440903106502

Räsänen, K. (2012). “'That's dangerous': Autonomous development work as a source of renewal in Academia," in Managing reform in universities: the dynamics of culture, identity and organisational change, eds. B. Stensaker, J. Välimaa, and C. S. Sarrico (Basingstoke: Palgrave Macmillan). doi: 10.1057/9781137284297_10

Räsänen, K. (2014). "Academic capitalism and practical activity: extending the research program," in Academic Capitalism in the Age of Globalization, eds B. Cantwell and I. Kauppinen (Baltimore: Johns Hopkins University Press), 94-112.

Räsänen, K. (2015). Fire and water combined: Understanding the relevance of working life studies through a concept of practical activity. Nordic J. Working Life Stud. 5, 47-62. doi: 10.19154/njwls.v5i3a.4833

Räsänen, K., and Mäntylä, H. (2001). Preserving academic diversity: promises and uncertainties of PAR as a survival strategy. Organization 8, 299-318. doi: 10.1177/1350508401082015

Räsänen, K., and Trux, M.-L. (2012). Työkirja: Ammattilaisen Paluu. Helsinki: Kansanvalistusseura.

Reckwitz, A. (2002). Toward a theory of social practices: a development in culturalist theorizing. Eur. J. Soc. Theor. 5, 243-263. doi: $10.1177 / 13684310222225432$

Reynolds, K., Block, D., and Bradley, K. (2018). Food justice scholar-activism and activist- scholarship: working beyond dichotomies to deepen social justice praxis. ACME 17, 988-998.

Riessman, K. K. (2008). Narrative Methods for the Human Sciences. Los Angeles: SAGE Publications.

Robertson, M. (2014). Sustainability Principles and Practice. London: Routledge. doi: $10.4324 / 9780203768747$

Routledge, P., and Derickson, K. D. (2015). Situated solidarities and the practice of scholar-activism. Environ. Plan. D 33, 391-407. doi: $10.1177 / 0263775815594308$

Salminen, A. (2016). Omavaraistava asubjektivaatio eli ei-inhimillinen egontuho fossiilimoderniteettia vastaan. Elonkehä 3.

Sandberg, J., and Tsoukas, H. (2011). Grasping the logic of practice: theorizing through practical rationality. AMR 36, 338-360. doi: 10.5465/amr.2009.0183

Spalding, N. J., and Phillips, T. (2007). Exploring the use of vignettes: from validity to trustworthiness. Qual. Health Res. 17, 954-962. doi: $10.1177 / 1049732307306187$

Starr, A. (2010). Local food: a social movement? Cult. Stud. 10, 479-490. doi: $10.1177 / 1532708610372769$

Stengers, I. (2017). Another Science is Possible: a Manifesto for Slow Science. English edition. Cambridge: Polity. doi: 10.1163/9789462096448_004

Wakefield, S. E. L. (2007). Reflective action in the academy: exploring praxis in critical geography using a "food movement" case study. Antipode 39, 331-354. doi: 10.1111/j.1467-8330.2007.00524.x

Weber, K., Heinze, K. L., and DeSoucey, M. (2008). Forage for thought: mobilizing codes in the movement for grass-fed meat and dairy products. Adm. Sci. Q 53, 529-567. doi: 10.2189/asqu.53.3.529

Zhang, W., Ricketts, T. H., Kremen, C., Carney, K., and Swinton, S. M. (2007). Ecosystem services and dis-services to agriculture. Ecol. Econ. 64, 253-260. doi: 10.1016/j.ecolecon.2007.02.024

Zigon, J. (2009). Within a range of possibilities: morality and ethics in social life. Ethnos 74, 251-276. doi: 10.1080/00141840902940492

Conflict of Interest: The authors declare that the research was conducted in the absence of any commercial or financial relationships that could be construed as a potential conflict of interest.

Copyright (C) 2020 Kallio and Houtbeckers. This is an open-access article distributed under the terms of the Creative Commons Attribution License (CC BY). The use, distribution or reproduction in other forums is permitted, provided the original author(s) and the copyright owner(s) are credited and that the original publication in this journal is cited, in accordance with accepted academic practice. No use, distribution or reproduction is permitted which does not comply with these terms. 